\title{
ADAPTASI DAN VALIDASI SKALA STRATEGI SIBLING CONFLICT
}

\section{Primatia Yogi Wulandari, Dewi Retno Suminar, Wiwin Hendriani}

\author{
Fakultas Psikologi, Universitas Airlangga \\ Kampus B UNAIR, Jl. Airlangga No. 4-6, Surabaya, Indonesia 60286 \\ primatia.yogi@psikologi.unair.ac.id
}

\begin{abstract}
Sibling conflict has some influences on children's development, positively and negatively. It is not only about the frequency, but also about the strategies used in managing conflict. The main purpose of this study was to adapt and to validate Sibling Conflict Strategy Scale developed by Recchia (2009), so it can be used by parents in Indonesia to identify their children's strategies. The process of adaptation was guided by the International Testing Commission (ITC) Guidelines model for test adaptation, which include forward - backward translation processes, followed by expert reviews to test language and conceptual equivalence. Then, we conducted the validation process by testing the Content Validity Index (CVI) and Confirmatory Factor Analysis (CFA). Two hundred and six parents in Surabaya who have children in the age range of 52-87 months $(M=71.21)$ were participated in the pilot study. The result showed that each indicator, dimension, and construct met all the Goodness of Fit criteria (RMSEA $\leq .08 ; \mathrm{CFI} \geq .9$ ). In addition, the value of Construct Reliability $(\mathrm{CR}) \geq .70$ and Average Variance Extracted (AVE) $\geq .50$ were also obtained. Thus, the Sibling Conflict Strategy Scale can be used as a valid and reliable measurement to measure children's sibling conflict strategies in Indonesia.
\end{abstract}

Keywords: adaptation; validation; sibling conflict strategy; scale

\begin{abstract}
Abstrak
Sibling conflict dapat berdampak positif dan negatif terhadap perkembangan anak. Aspek yang mempengaruhi dampak tersebut bukan hanya masalah frekuensi, namun lebih pada strategi yang digunakan saat konflik. Penelitian ini ditujukan untuk mengadaptasi dan memvalidasi Skala Strategi Sibling Conflict yang dikembangkan oleh Recchia (2009), sehingga diharapkan dapat membantu orangtua di Indonesia dalam mengidentifikasi strategi yang dilakukan anak-anaknya. Adaptasi dilakukan berdasarkan pedoman adaptasi alat ukur dari International Test Commission (ITC), yang meliputi proses forward - backward translation, dilanjutkan dengan expert review untuk menguji ekuivalensi bahasa dan konseptual. Adapun proses validasi dilakukan dengan menguji validitas isi, melalui Content Validity Index (CVI), dan validitas konstruk, menggunakan Confirmatory Factor Analysis (CFA). Uji coba dilakukan kepada 206 orangtua yang memiliki anak di Surabaya, dengan rentang usia anak 52 87 bulan (rerata $=71.21$ ). Berdasarkan proses uji coba ini, diketahui bahwa setiap indikator, dimensi, dan konstruk memenuhi semua kriteria Goodness of Fit (RMSEA $\leq 0,08$; CFI $\geq 0,9$ ). Di samping itu, diperoleh juga nilai Construct Reliability (CR) $\geq 0,70$ dan Average Variance Extracted (AVE) $\geq 0,50$. Dengan demikian, Skala Strategi Sibling Conflict dapat digunakan sebagai alat ukur yang valid dan reliabel untuk mengukur strategi sibling conflict anak di Indonesia.
\end{abstract}

Kata kunci: adaptasi; validasi; strategi sibling conflict; skala

\section{PENDAHULUAN}

Para ahli psikologi perkembangan meyakini bahwa konflik dengan saudara (sibling conflict) memiliki dampak yang signifikan terhadap perkembangan anak, terlebih pada anak-anak usia dini yang memang paling sering terjadi konflik dengan saudaranya (Perlman, Ross, \& Garfinkel, 2009). Dampak tersebut dapat bersifat negatif maupun positif. Penelitian Buist, Deković, dan Prinzie (2013) membuktikan adanya hubungan antara sibling conflict dengan gangguan perilaku, baik yang bersifat internal maupun eksternal. Semakin sedikit konflik yang terjadi pada relasi anak dengan saudaranya, maka 
semakin kecil pula kecenderungan anak mengalami gangguan perilaku. Menurut Buist, dkk. (2013) serta Whiteman, McHale, dan Soli (2011), mekanisme hubungan tersebut terjadi melalui mekanisme belajar sosial (social learning). Anak belajar perilaku negatif saat konflik dengan saudaranya, untuk kemudian menggunakan model perilaku yang sama pada konteks sosial yang lain. Hasil penelitian yang sama diperoleh Scrimgeour, Mariotti, dan Blandon (2017), yaitu ada hubungan positif antara sibling conflict dengan gangguan perilaku yang bersifat internal pada anak-anak usia dini. Pada penelitian-penelitian longitudinal, dampak negatif sibling conflict tersebut bahkan dapat membuat anak kesulitan untuk mengembangkan rasa percaya dan ikatan emosional dengan saudara maupun temantemannya, baik di masa kanak-kanak maupun masa berikutnya (Bowes, Wolke, Joinsonn, Lereya, \& Lewis, 2014; Campione-Barr \& Smetana, 2010). Di sisi lain, konflik sebenarnya dapat menjadi wadah bagi anak untuk memahami pikiran, pandangan, keinginan, dan keyakinan orang lain. Secara spesifik, Kramer (2014) menyatakan bahwa konflik dalam kehidupan sehari-hari memberikan berbagai kesempatan untuk pengembangan kemampuan pemahaman emosi pada anak. Schleien, Ross, dan Ross (2010) menambahkan bahwa dalam sibling conflict, anak juga belajar memaafkan dan melakukan rekonsiliasi. Dengan demikian, dapat disimpulkan bahwa sibling conflict tidak selalu bersifat negatif. Kramer (2010) bahkan menegaskan bahwa menghapuskan sibling conflict hanya akan berdampak negatif terhadap kemampuan penyelesaian masalah dan regulasi emosi anak.

Dampak positif atau negatif dari sibling conflict sebenarnya tidak hanya tergantung pada tinggi rendahnya frekuensi konflik yang terjadi, namun juga pada strategi yang dilakukan saat terjadi konflik. Deutsch, Coleman, dan Marcus (2006) menyatakan ada dua jenis strategi ketika seseorang menghadapi konflik, yaitu strategi destruktif dan konstruktif. Strategi destruktif adalah strategi yang bersifat memaksa dan mengandalkan kekuatan fisik atau psikologis dalam menyelesaikan masalah. Strategi ini terjadi ketika anak menggunakan cara-cara penyelesaian konflik yang bersifat fisik atau negatif, seperti memaksa, mengolok-olok, atau tindakan agresif. Biasanya strategi destruktif dilakukan oleh anak yang lebih tua kepada adiknya (Abuhatoum \& Howe, 2013; Bowes, dkk., 2014; Tucker, Finkelhor, Shattuck, \& Turner, 2013). Adapun strategi konstruktif dicirikan dengan adanya argumentasi atau diskusi yang rasional, disertai logika dan penalaran, sehingga menghasilkan sebuah pemahaman satu sama lain. Saat anak menyelesaikan konflik dengan strategi konstruktif, maka dapat dikatakan bahwa konflik bersifat konstruktif. Konflik yang konstruktif ini ditandai dengan intensitas emosi yang rendah, diselesaikan melalui negosiasi, serta dapat meningkatkan kualitas relasi anak dengan saudaranya (Deutsch, dkk., 2006; Ross \& Lazinski, 2014). Pengetahuan tentang konflik-konflik konstruktif inilah yang akan membantu orangtua dan orang-orang di sekitar anak dalam membimbing sibling conflict ke arah yang lebih positif (Tucker \& Finkelhor, 2015).

Mempertimbangkan pentingnya strategi yang digunakan saat konflik ini, maka para peneliti berusaha untuk membuat alat ukur yang dapat mengidentifikasi strategi sibling conflict pada anak. Beberapa alat ukur yang dikembangkan adalah subskala Conflict/ Aggression pada Sibling Inventory of Behavior Scale (SIB; Volling \& Blandon, 2005) dan subskala Sibling Agonism pada Parental Expectations and Perceptions of Children's Sibling Relationships Questionnaire (PEPC-SRQ; Kramer, 2010; Kramer \& Baron, 1995). Hanya saja, alat-alat ukur tersebut lebih berfokus pada dimensi negatif dan destruktif dari strategi konflik yang dilakukan anak, yang dapat terlihat pada item-item PEPCSRQ. Contoh pernyataan item pada skala tersebut adalah "How frequently do you think each of the following occurs in this kind of relationships? (1) physical aggression 
(hiting, pushing, etc., (2) anger or hostility, (3) fighting over territory or space". Recchia (2009) pun mengembangkan alat ukur Sibling Conflict Strategy Scale (SCSS) yang memasukkan kedua dimensi strategi. Dalam hal ini, sibling conflict dipandang dapat diatasi dengan cara-cara yang destruktif, negatif dan bermusuhan, tapi juga dapat diselesaikan dengan diskusi dan negosiasi, yang merupakan bentuk-bentuk strategi konstruktif. SCSS ini telah dipakai oleh penelitian terbaru (Rajput, 2014).

Di Indonesia, alat ukur tentang strategi Sibling Conflict masih kurang begitu berkembang. Ada beberapa penelitian yang mengupas strategi sibling conflict, tapi alat ukur yang digunakan sudah sangat lama, yaitu Sibling Relationship Questionnaire dari Furman dan Burhmester (1985; dalam Naibaho, Victoriana, \& Tjoeng, 2017). Ada pula peneliti yang justru menggunakan sibling rivalry scale dan bukan berfokus pada pengukuran strategi sibling conflict sendiri (Muarifah \& Puspitasari, 2018; Turniati \& Nusantoro, 2015). Dengan demikian, penelitian ini bertujuan untuk melakukan adaptasi dan validasi SCSS dari Recchia (2009), dalam rangka mendapatkan alat ukur yang valid dan reliabel untuk mengukur strategi Sibling Conflict pada anak-anak di Indonesia.

\section{METODE}

SCSS dikembangkan oleh Recchia (2009). Pada skala ini, orangtua mengukur penggunaan strategi konflik yang bersifat konstruktif dan destruktif selama terjadi konflik antara anak dan saudaranya di rumah. Secara spesifik, ada 10 item strategi konstruktif yang terdiri atas negosiasi kognitif dan negosiasi emosi serta 10 item strategi destruktif yaitu agresi psikologis dan kekerasan fisik. Orangtua diminta melakukan penilaian atau rating dalam bentuk skala Likert (1: tidak pernah, 2: jarang, 3: kadangkadang, 4: sering, 5: selalu). Pada penelitian ini, respon netral atau pilihan ke-3 tidak akan digunakan untuk menghindari central tendency effect (Eckes, 2009), yaitu kecenderungan untuk memilih alternatif respon atau jawaban yang berada di tengah. Terkait dengan hal ini, beberapa peneliti menunjukkan adanya kecenderungan untuk memilih jawaban yang berada di tengah dan menghindari jawaban di pilihan respon yang terletak di bagian bawah atau atas pada budaya dan masyarakat kolektif seperti di Asia (Harzing, dkk., 2009).

Dalam sistem skoring, item-item pada skala destruktif diskor terbalik atau berlawanan, dan semua item dijumlahkan sehingga mendapatkan total. Semakin tinggi total skor, maka semakin konstruktif strategi sibling conflict yang dimiliki anak. Skala ini terbukti memiliki tingkat validitas dan reliabilitas yang cukup baik. Dalam penelitiannya, Recchia dan Howe (2009) mengkorelasikan skor skala konstruktif dan destruktif pada dua orang anak. Koefisien korelasi pada anak pertama adalah sebesar 0,67, sedangkan pada anak kedua sebesar 0,61. Adapun reliabilitas konsistensi internal untuk kedua skala adalah 0,87 dan 0,85 .

Dalam proses adaptasi, peneliti menggunakan International Test Commission (ITC) Guidelines for Test Adaptation (2016) sebagai pedoman. Pada tahapan persiapan, peneliti meminta ijin dari pembuat alat ukur dengan mengirimkan pesan melalui melalui email. Di samping itu, peneliti juga memilih sekelompok penerjemah dan para ahli yang akan terlibat di dalam proses adaptasi. Pemilihan dilakukan berdasarkan beberapa pertimbangan, seperti latar belakang pendidikan, kemampuan berbahasa Indonesia dan Inggris, serta fokus penelitian.

Tahap berikutnya adalah tahapan translasi dengan menggunakan metode forwardbackward (Gudmundsson, 2009; Sousa \& Rojjanasrirat, 2011). Di tahap awal, skala asli yang berbahasa Inggris ditranslasi ke dalam bahasa Indonesia, atau disebut juga dengan forward translation. Proses translasi ini dilakukan oleh peneliti dan seorang kolega yang sama-sama memiliki latar belakang S1 
dan S2 Psikologi serta menguasai kemampuan berbahasa Inggris yang lancar. Hasil akhir proses forward translation ini berupa sintesa kedua hasil translasi, yang disebut dengan skala versi forward translation. Pada tahapan berikutnya, dilakukan backward translation oleh dua orang. Kedua penerjemah ini sama sekali tidak melihat alat ukur asli yang digunakan dalam penelitian ini. Hasil sintesis dari kedua backward translation akan diberikan kepada para expert reviewers di tahapan berikutnya untuk melihat perbandingan antara hasil translasi dan alat ukur yang asli.

Di tahapan selanjutnya, peneliti melibatkan tiga orang ahli untuk melakukan penilaian terhadap ekuivalensi dan validitas isi alat ukur. Untuk mempermudah proses penilaian, peneliti menggunakan rating scales Jeanrie dan Bertrand (1999) serta Sperber (2004), sebagaimana yang disarankan dalam ITC Guidelines for Adaptation (2016). Teknik ini juga digunakan di beberapa proses adaptasi alat ukur terbaru (Thien \& Ong, 2016; Viñas Poch, González Carrasco, Gras Pérez, Jane Ballabriga, \& Casas Aznar, 2015). Komponen yang dinilai dalam rating scales tersebut adalah terkait tingkat perbandingan (comparability) dan kesamaan (similarity) item antara skala versi orisinal dengan versi backward translation, dengan range skala berkisar $1-7$. Comparability merujuk pada tingkat kesamaan bahasa, frase, istilah, kata, dan kalimat secara formal. Item-item yang sangat identik dan tidak ada perbedaan diberi skor 1, sedangkan item-item yang sama sekali tidak identik diskor 7. Similarity mengacu pada tingkat kesamaan makna antara dua versi item, meskipun istilah yang digunakan berbeda. Item-item yang memiliki makna yang identik diskor 1, sedangkan yang memiliki makna sangat berbeda diskor 7 . Tahapan ini merupakan langkah terakhir dalam proses adaptasi.

Pada proses validasi, peneliti menggunakan dua pendekatan, yaitu bukti yang didasarkan pada isi (evidence based on test content) serta didasarkan pada struktur internal (evidence based on internal structure) (Cizek, Bowen, \& Church, 2010). Validitas pertama disebut juga dengan validitas isi, yaitu membuktikan sejauh mana item-item mere-presentasikan konstruk yang diukur. Proses validasi ini dilakukan di tahap expert review, dimana peneliti meminta para ahli memberikan rating (skala 1 - 4) pada tiga parameter, yaitu: relevansi (relevancy), kepentingan (importancy), dan kejelasan (clarity). Parameter relevansi adalah sejauh mana relevansi item dengan konstruk yang diukur, sedangkan kepentingan adalah seberapa penting item tersebut bila dikaitkan dengan konstruk dan konteks penelitian. Adapun parameter kejelasan berfokus pada apakah item sudah cukup jelas dan dapat dipahami (Khami, Razeghi, \& Mirmohammadi, 2016; Rodrigues, Adachi, Beattie, \& MacDermid, 2017; Sala, dkk., 2017). Dari rating $1-4$, item yang baik adalah yang dinilai 3 dan 4 , sedangkan item yang kurang baik adalah yang dinilai 1 dan 2 Berikutnya, berdasarkan tingkat kesepakatan para ahli, yang dilihat dari proporsi penilaian, maka akan dihitung Content Validity Index (CVI). CVI inilah yang menjadi bukti empiris terkait validitas isi dari alat ukur (Beckstead, 2009; McCoach, Gable, \& Madura, 2013).

Tahapan validasi kedua diperoleh melalui uji coba. Diawali dari pembuatan skala melalui aplikasi Surveymonkey, peneliti kemudian menyebarkan link skala tersebut melalui email, facebook, whatsapp, dan media sosial lainnya. Sejumlah 206 orangtua yang memiliki anak berusia $52-87$ bulan $(M=$ $71,21)$ berpartisipasi dalam uji coba ini. Bila dilihat berdasarkan jenis kelamin, terdiri atas $47,6 \%$ anak laki-laki dan 52,4\% anak perempuan. Validitas melalui pendekatan ini disebut juga validitas konstruk, yaitu dengan menggunakan Confirmatory Factor Analysis (CFA) untuk menguji struktur internal alat ukur. Dalam penelitian ini, akan dilakukan Second Order Confirmatory Factor Analysis dikarenakan konstruk sibling conflict merupakan konstruk multidimensional. Adapun analisis statistik menggunakan program AMOS 23, dengan berpedoman 
pada beberapa fit indexes untuk menguji fit tidaknya model. Fit indexes yang dijadikan pedoman pada penelitian ini ada 4 buah, yaitu (1) p-value, (2) Root Mean Square Error of Approximation (RMSEA), (3) Comparative Fit Index (CFI), dan (4) Normed Fit Index (NFI). Bila model sudah memenuhi ketentuan fit (Ghozali, 2017), maka peneliti mencermati factor loading pada setiap item yang menyusun konstruk strategi sibling conflict.

Dari hasil uji coba, penelitian ini juga melakukan pengujian reliabilitas, melalui pengukuran nilai reliabilitas konstruk (Construct Reliability atau Composite Reliability; CR) dan nilai rerata varians terekstrasi (Average Variance Extracted; AVE). Pada CR, nilai minimal yang ditetapkan untuk mengindikasikan bahwa konstruk dapat diterima adalah sebesar 0,7 (Ghozali, 2017). Adapun nilai AVE minimal yang direkomendasikan adalah 0,5 (Ghozali, 2017).

\section{HASIL DAN PEMBAHASAN}

Proses adaptasi dilakukan secara kualitatif dan kuantitatif. Pada tahapan forward translation, ada satu kata yang sempat didiskusikan, yaitu kata 'breaks" pada item 10. Salah satu penerjemah mengartikannya dengan "meme-cahkan", sedangkan penerjemah lain meng-artikan dengan kata "merusak". Berdasarkan konsensus dari kedua penerjemah, maka kata "merusak" dianggap lebih mewakili arti katanya. Adapun di tahapan backward translation, ada beberapa perbedaan istilah yang diberikan oleh para penerjemah. Di item nomor 5, kata "makes fun" di skala asli diterjemahkan menjadi "mocks", sedangkan istilah "sorry" di item nomor 12 diterjemahkan dengan kata "apologizes".

Secara kuantitatif, para ahli kemudian melakukan penilaian di rating scale yang menunjukkan dua tipe ekuivalensi, yaitu ekuivalensi bahasa (linguistic equivalence) dan ekuivalensi konseptual (conceptual equivalence) (Jeanrie \& Bertrand, 1999; Swanepoel \& Krüger, 2011). Untuk setiap item, dihitung skor rerata dari penilaian ketiga ahli. Menurut Sperber, (2004), item yang ekuivalen adalah item-item dengan skor rerata $<4$. Berdasarkan hasil perhitungan tingkat comparability dan similarity item, diperoleh hasil bahwa tidak ada item yang memiliki skor rerata lebih dari 4. Rangkuman skor rerata pada setiap item dapat dilihat di Tabel 1, sedangkan skor rerata pada total skala adalah sebesar 1,40 untuk tingkat comparability dan 1,33 untuk tingkat similarity item. Dapat disimpulkan bahwa para ahli meyakini hanya sedikit terjadi perbedaan di dalam bahasa pada skala adaptasi serta tidak ada masalah pemaknaan yang berarti di antara kedua versi tersebut meskipun mungkin istilah yang digunakan berbeda.

Tabel 1.

Hasil Analisis Ekuivalensi Berdasarkan Expert Review

\begin{tabular}{|c|c|c|c|c|}
\hline \multirow{2}{*}{ Skala Asli } & \multirow{2}{*}{$\begin{array}{c}\text { Skala versi } \\
\text { Back Translation }\end{array}$} & \multicolumn{2}{|c|}{ Mean Score } & \multirow{2}{*}{ Keterangan } \\
\hline & & Comparability & Similarity & \\
\hline $\begin{array}{l}\text { 1. He/she stops talking to his/her } \\
\text { sister/brother. }\end{array}$ & $\begin{array}{l}\text { 1. He/she stops talking to } \\
\text { his/her sibling }\end{array}$ & 1,00 & 1,00 & Ekuivalen \\
\hline $\begin{array}{l}\text { 2. He/she let his/her sister/brother } \\
\text { have his/her own way. }\end{array}$ & 2. He/she lets his/her sibling. & 3,00 & 3,00 & Ekuivalen \\
\hline $\begin{array}{l}\text { 3. He/she solves problems with } \\
\text { his/her sister/brother. }\end{array}$ & $\begin{array}{l}\text { 3. He/she solves the problem } \\
\text { with his/her sibling. }\end{array}$ & 1,33 & 1,33 & Ekuivalen \\
\hline $\begin{array}{l}\text { 4. He/she calls his/her } \\
\text { sister/brother bad names. }\end{array}$ & $\begin{array}{l}\text { 4. He/she calls his/her } \\
\text { sibling badly. }\end{array}$ & 2,00 & 2,00 & Ekuivalen \\
\hline $\begin{array}{l}\text { 5. He/she makes fun of his/her } \\
\text { sister/brother. }\end{array}$ & $\begin{array}{l}\text { 5. He/she mocks his/her } \\
\text { sibling. }\end{array}$ & 1,67 & 1,67 & Ekuivalen \\
\hline
\end{tabular}


Lanjutan Tabel 1. Hasil Analisis Ekuivalensi Berdasarkan Expert Review

\begin{tabular}{|c|c|c|c|c|}
\hline $\begin{array}{l}\text { 6. He/she asks his/her sister/brother } \\
\text { what he/she wants. }\end{array}$ & 6. He/she asks what his/her sibling wants. & 1,33 & 1,00 & Ekuivalen \\
\hline $\begin{array}{l}\text { 7. He/she hits or kicks his/her } \\
\text { sister/brother. }\end{array}$ & 7. He/she hits or kicks his/her sibling. & 1,00 & 1,00 & Ekuivalen \\
\hline $\begin{array}{l}\text { 8. He/she asks his/her sister/brother } \\
\text { how he/she feels. }\end{array}$ & 8. He/she asks how his/her sibling feels. & 1,00 & 1,00 & Ekuivalen \\
\hline $\begin{array}{l}\text { 9. He/she says nice things to his/her } \\
\text { sister/brother. }\end{array}$ & 9. He/she talks nicely to his/her sibling. & 1,67 & 1,67 & Ekuivalen \\
\hline $\begin{array}{l}\text { 10. He/she breaks his/her } \\
\text { sister/brother's things. }\end{array}$ & 10. He/she breaks his/her sibling's stuff. & 1,33 & 1,33 & Ekuivalen \\
\hline $\begin{array}{l}\text { 11. He/she yells or screams at } \\
\text { his/her sister/brother. }\end{array}$ & 11. He/she yells at her/his sibling. & 1,33 & 1,33 & Ekuivalen \\
\hline $\begin{array}{l}\text { 12. He/she says he/she is sorry to } \\
\text { his/her sister/brother. }\end{array}$ & 12. He/she apologizes to his/her sibling. & 1,33 & 1,00 & Ekuivalen \\
\hline $\begin{array}{l}\text { 13. He/she makes his/her } \\
\text { sister/brother cry. }\end{array}$ & 13. He/she makes his/her sibling cries. & 1,00 & 1,00 & Ekuivalen \\
\hline $\begin{array}{l}\text { 14. He/she talks calmly to his/her } \\
\text { sister/brother. }\end{array}$ & 14. He/she talks calmly to his/her sibling. & 1,00 & 1,00 & Ekuivalen \\
\hline $\begin{array}{l}15 . \mathrm{He} / \mathrm{she} \text { asks his/her sister/brother } \\
\text { how to solve the problems }\end{array}$ & $\begin{array}{l}\text { 15. He/she asks how to solve the problem } \\
\text { to his/her sibling. }\end{array}$ & 1,33 & 1,00 & Ekuivalen \\
\hline $\begin{array}{l}\text { 16. He/she lies to his/her } \\
\text { sister/brother. }\end{array}$ & 16. He/she lies to his/her sibling. & 1,00 & 1,00 & Ekuivalen \\
\hline $\begin{array}{l}\text { 17. He/she helps his/her } \\
\text { sister/brother get what he/she wants. }\end{array}$ & $\begin{array}{l}\text { 17. He/she helps to realize his/her sibling's } \\
\text { wish. }\end{array}$ & 1,67 & 1,33 & Ekuivalen \\
\hline $\begin{array}{l}\text { 18. He/she tells his/her sister/brother } \\
\text { will hurt his/her sister/brother. }\end{array}$ & 18. He/she threats to hurt his/her sibling. & 1,33 & 1,33 & Ekuivalen \\
\hline $\begin{array}{l}\text { 19. He/she blames his/her } \\
\text { sister/brother. }\end{array}$ & 19. He/she blames his/her sibling. & 1,00 & 1,00 & Ekuivalen \\
\hline $\begin{array}{l}20 . \mathrm{He} / \text { she tries to find a way for } \\
\text { both of them to get what they want. }\end{array}$ & $\begin{array}{l}\text { 20. He/she tries to find a way to } \\
\text { accommodate what he/she and his/her } \\
\text { sibling wants. }\end{array}$ & 1,67 & 1,67 & Ekuivalen \\
\hline
\end{tabular}

Proses validasi diawali dengan pengujian CVI. Ada dua tipe CVI untuk mengukur kesepakatan tentang relevansi, kepentingan, serta kejelasan item, yaitu I-CVI (Item-CVI) dan S-CVI (Scale-CVI) (Beckstead, 2009; Polit, Beck, \& Owen, 2007). I-CVI lebih melibatkan validitas isi item secara individual sedangkan S-CVI digunakan untuk mengukur validitas isi dari skala secara keseluruhan. Nilai pada kedua CVI ini yang dijadikan pertimbangan dalam menyeleksi item. Langkah pertama adalah menghitung I-CVI yang dilihat dari jumlah ahli yang memberi rating 3 atau 4 pada setiap item, lalu dibagi jumlah ahli secara keseluruhan (Gambar 1). Hasil perhitungan I-CVI dapat dilihat di Tabel 2.

Item yang memiliki I-CVI minimal 0,78 merupakan item yang baik dan dianggap memiliki bukti empiris terkait validitas isinya (Polit dkk., 2007). Adapun item-item yang memiliki I-CVI yang sangat rendah akan dihapus. Secara lebih spesifik, Zamanzadeh dkk., (2015) menyatakan bahwa item yang dihapus adalah yang memiliki I-CVI di bawah 0,70, sedangkan item dengan I-CVI berkisar $0,70-0,78$ masih dapat dipakai dengan beberapa revisi atau modifikasi. Pada penelitian ini, semua item dapat dipakai, dikarenakan I-CVI yang sangat tinggi, yaitu 1,00 (lihat Tabel 2). Tingginya I-CVI ini dikarenakan ketiga ahli sama-sama sepakat bahwa semua item memiliki tingkat relevansi, kepentingan, dan kejelasan yang tinggi.

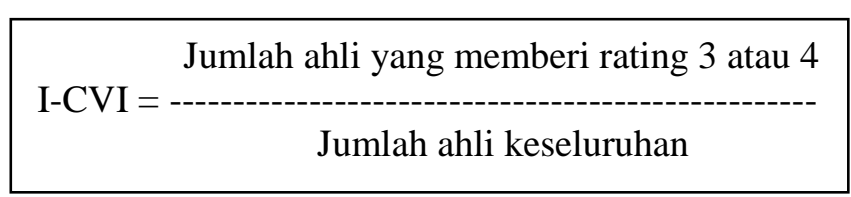

Gambar 1. Rumus I-CVI 
Tabel 2.

Rekapitulasi Perhitungan I-CVI

\begin{tabular}{ccccc}
\hline Item & Relevansi & Kepentingan & Kejelasan & Tindakan terhadap Item \\
\hline 1 & 1,00 & 1,00 & 1,00 & Dipakai \\
2 & 1,00 & 1,00 & 1,00 & Dipakai \\
3 & 1,00 & 1,00 & 1,00 & Dipakai \\
4 & 1,00 & 1,00 & 1,00 & Dipakai \\
5 & 1,00 & 1,00 & 1,00 & Dipakai \\
6 & 1,00 & 1,00 & 1,00 & Dipakai \\
7 & 1,00 & 1,00 & 1,00 & Dipakai \\
8 & 1,00 & 1,00 & 1,00 & Dipakai \\
9 & 1,00 & 1,00 & 1,00 & Dipakai \\
10 & 1,00 & 1,00 & 1,00 & Dipakai \\
11 & 1,00 & 1,00 & 1,00 & Dipakai \\
12 & 1,00 & 1,00 & 1,00 & Dipakai \\
13 & 1,00 & 1,00 & 1,00 & Dipakai \\
14 & 1,00 & 1,00 & 1,00 & Dipakai \\
15 & 1,00 & 1,00 & 1,00 & Dipakai \\
16 & 1,00 & 1,00 & 1,00 & Dipakai \\
17 & 1,00 & 1,00 & 1,00 & Dipakai \\
18 & 1,00 & 1,00 & 1,00 & Dipakai \\
19 & 1,00 & 1,00 & 1,00 & Dipakai \\
20 & 1,00 & 1,00 & 1,00 & Dipakai \\
\hline
\end{tabular}

Setelah itu, dilakukan pengujian S-CVI pada setiap parameter. S-CVI ditentukan dengan menghitung rata-rata I-CVI, yaitu jumlah skor I-CVI dibagi jumlah item keseluruhan (Gambar 2). Adapun hasilnya ditampilkan pada Tabel 3. Menurut Polit dkk. (2007), SCVI yang baik adalah 0,90 ke atas, yang mengindikasikan adanya validitas isi yang baik. Skala Strategi Sibling Conflict memiliki S-CVI sebesar 1,00, baik pada parameter relevansi, kepentingan, maupun kejelasan (lihat Tabel 3). Dengan demikian, dapat dikatakan bahwa skala ini menunjukkan validitas isi yang dapat diterima.

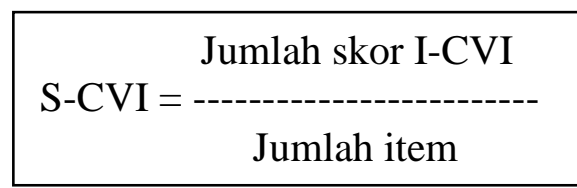

Gambar 2. Rumus I-CVI

Tabel 3.

Rekapitulasi Perhitungan S-CVI Berdasarkan Parameter

\begin{tabular}{cccc}
\hline \multicolumn{3}{c}{ Parameter } & \multirow{2}{*}{ Kesimpulan } \\
\cline { 1 - 3 } Relevansi & Kepentingan & Kejelasan & Semua parameter menunjukkan nilai di atas 0,90 \\
\hline 1,00 & 1,00 & 1,00 & S
\end{tabular}

Langkah berikutnya adalah mencari buktibukti validitas konstruk berdasarkan data yang diperoleh saat uji coba. Pada pengujian pertama, model yang dihasilkan tidak fit, oleh karenanya dilakukan beberapa modifikasi sebagaimana yang disarankan oleh AMOS. Berdasarkan hasil Second Order Confirmatory Factor Analysis, diperoleh path diagram yang ditampilkan pada Gambar 3. Hasil pengujian Goodness of Fit untuk konstruk strategi sibling conflict ditampilkan pada Tabel 4. Tiga dari empat kriteria Goodness of Fit menunjukkan indikasi good fit, yaitu p-value, RMSEA, dan CFI, sedangkan satu kriteria lainnya termasuk marginal fit (Ghozali, 2017). Dengan 
mempertimbangkan hasil yang diperoleh, dapat disimpulkan bahwa model pengukuran konstruk strategi sibling conflict telah memenuhi ketentuan Goodness of Fit.

Tabel 4.

Hasil Goodness of Fit Skala Strategi Sibling Conflict

\begin{tabular}{cccc}
\hline $\begin{array}{c}\text { Kriteria } \\
\begin{array}{c}\text { Goodness } \\
\text { of Fit }\end{array}\end{array}$ & $\begin{array}{c}\text { Tingkat } \\
\text { Kesesuaian } \\
\text { yang Bisa } \\
\text { Diterima }\end{array}$ & $\begin{array}{c}\text { Hasil } \\
\text { Estimasi }\end{array}$ & Keterangan \\
\hline p-value & $>0,05$ & 0,184 & good fit \\
RMSEA & $\leq 0,08$ & 0,024 & good fit \\
CFI & $\geq 0,90$ & 0,985 & $\begin{array}{c}\text { good fit } \\
\text { Marginal } \\
\text { fit }\end{array}$ \\
NFI & $\geq 0,90$ & 0,878 & \\
\hline
\end{tabular}

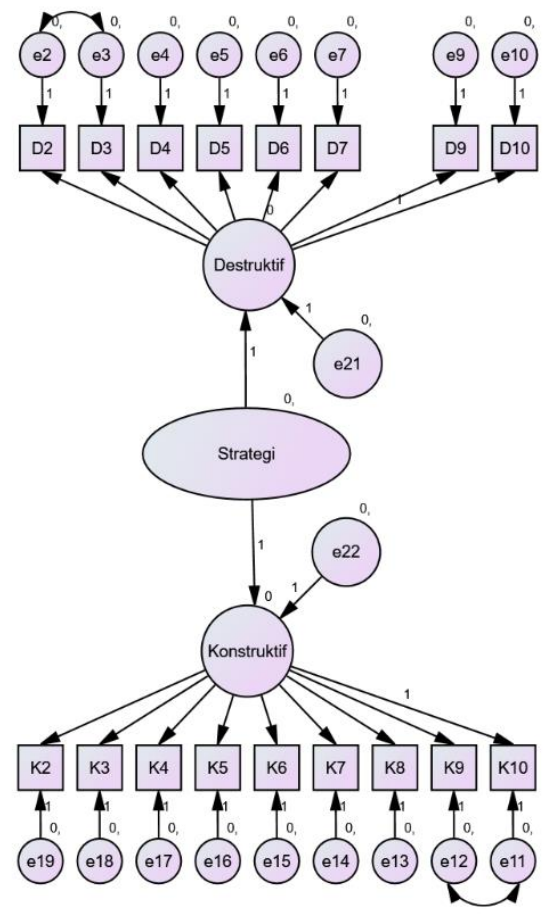

Gambar 3. Path Diagram

Setelah model fit, maka peneliti mencermati factor loading setiap item yang menyusun konstruk strategi sibling conflict. Pada dimensi destruktif, ada penghapusan itemitem dengan factor loading di bawah 0,30 (Ghozali, 2017), yaitu D1 dan D8. Item D1 ternyata juga dihapus di dalam penelitian Recchia dan Howe (2009) dikarenakan korelasinya yang sangat rendah dengan skor total. Begitu pula pada dimensi konstruktif, ada satu item yang dihapus. Dengan demikian, factor loading dalam standardized estimates pada semua item lebih besar dari 0,30 (Tabel 5). Dalam dimensi destruktif, nilai factor loading terbesar ada pada item D4 dengan nilai 0,66 , sedangkan nilai factor loading terkecil pada item D9 dengan nilai 0,33 . Untuk dimensi konstruktif, nilai factor loading terbesar terdapat pada item $\mathrm{K} 8$ dengan nilai 0,77 , sedangkan nilai factor loading terkecil terdapat pada item K6 dengan nilai 0,34 . Berdasarkan hasil analisis tersebut, dapat disimpulkan bahwa 17 item yang merupakan observed variable mempunyai validitas yang baik terhadap latent variable-nya pada konstruk strategi sibling conflict (Tabel 5).

Tabel 5.

Factor Loading Skala Strategi Sibling

\begin{tabular}{ccc}
\multicolumn{3}{c}{ Conflict } \\
\hline Dimensi/Item & $\begin{array}{c}\text { Factor } \\
\text { Loading }\end{array}$ & $\begin{array}{c}\text { Jumlah } \\
\text { Item }\end{array}$ \\
\hline Destruktif & & \\
D2 & 0,49 & \\
D3 & 0,52 & \\
D4 & 0,66 & 8 \\
D5 & 0,49 & \\
D6 & 0,65 & \\
D7 & 0,52 & \\
D9 & 0,33 & \\
D10 & 0,62 & \\
Konstruktif & & \\
K2 & 0,70 & \\
K3 & 0,76 & \\
K4 & 0,73 & \\
K5 & 0,48 & 9 \\
K6 & 0,34 & \\
K7 & 0,60 & \\
K8 & 0,77 & \\
K9 & 0,53 & \\
K10 & 0,58 & \\
\hline Total & & 17 \\
\hline
\end{tabular}

Setelah mendapatkan bukti-bukti yang menegakkan validitas isi dan konstruk, peneliti melakukan pengujian reliabilitas. Koefisien CR menekankan pada seberapa jauh indikator ukur merefleksikan faktor laten yang disusun. Semakin besar indikator merefleksikan faktor latennya, maka semakin besar nilai reliabilitas pengukuran. Di samping itu, pengujian relia-bilitas juga dengan menggunakan nilai AVE. AVE menunjukkan 
total varians suatu konstruk yang dapat dijelaskan oleh pengukuran yang dilakukan. Untuk menghitung koefisien CR dan AVE, digunakan persamaan pada Gambar 4.

\begin{tabular}{|c|}
\hline (jumlah standard loading) $^{2}$ \\
\hline$(\text { jumlah standard loading })^{2}+$ jumlah kesalahan $p$ \\
\hline jumlah kuadrat standard loading \\
\hline $\begin{array}{l}\mathrm{AVE}=\mathrm{-} \\
\text { jumlah kuadrat standard loading }+ \text { jumlah kesalahan } \mathrm{p}\end{array}$ \\
\hline $\begin{array}{l}\text { Keterangan: } \\
\text { - Jumlah standard loading diambil dari factor loading } \\
\text { (standardized regression weight estimate), dengan } \\
\text { mengabaikan tanda }+/- \\
\text { - Jumlah kesalahan p (pengukuran) }=1-(\text { standard } \\
\text { loading) }{ }^{2}\end{array}$ \\
\hline
\end{tabular}

Gambar 4. Rumus CR dan AVE

Suatu konstruk dapat diterima bila memiliki nilai minimal sebesar 0,7 untuk CR dan 0,5 untuk AVE. Hasil uji CR dan AVE ini dapat dilihat di Tabel 6. Dapat disimpulkan bahwa semua nilai CR dan AVE melebihi batas ambangnya. Hal ini mengindikasikan bahwa tingkat reliabilitas pada konstruk strategi sibling conflict cukup tinggi. Dapat dikatakan juga bahwa indikator-indikator tersebut cukup konsisten untuk mengukur konstruknya. Konsistensi internal yang kuat ini juga ditemukan oleh Recchia (2009), dengan koefisien Cronbach Alpha sebesar 0,87 untuk subskala strategi konstruktif dan 0,85 untuk strategi destruktif.

Tabel 6.

Hasil Perhitungan CR dan AVE

\begin{tabular}{cccl}
\hline Dimensi & CR & AVE & Keterangan \\
\hline Konstruktif & 0,76 & 0,69 & Reliabel \\
Destruktif & 0,85 & 0,51 & Reliabel \\
\hline
\end{tabular}

\section{SIMPULAN}

Hasil penelitian ini menunjukkan bahwa Skala Strategi Sibling Conflict merupakan alat ukur yang valid dan reliabel untuk mengukur strategi Sibling Conflict pada anakanak di Indonesia. Dengan bentuknya yang berupa parent-report, maka skala ini dapat membantu orangtua mengidentifikasi strategi yang digunakan oleh anak-anaknya. Selanjutnya, orangtua dapat melakukan tindak lanjut dengan memperkuat strategistrategi yang bersifat konstruktif sekaligus mengubah strategi destruktif menjadi strategi yang lebih positif. Perlu diingat bahwa penggunaan skala ini hanya berlaku pada konflik yang terjadi pada anak-anak usia 52 87 bulan, oleh karenanya untuk penggunaan di luar usia tersebut, perlu dilakukan studi ulang. Di samping itu, skala ini hanya diujicobakan pada sampel orangtua dan anak di Surabaya. Penelitian di tempat lain sangat disarankan bila skala akan diperluas penggunaannya.

\section{DAFTAR PUSTAKA}

Abuhatoum, S. \& Howe, N. (2013). Power in sibling conflict during early and middle childhood. Social Development, 22(4), 738-754. doi:10.1111/sode.12021

Beckstead, J. W. (2009). Content validity is naught. International Journal of Nursing Studies, $\quad 46(9)$, 1274-1283. doi:10.1016/j.ijnurstu.2009.04.014

Bowes, L. N., Wolke, D., Joinson, C. J., Lereya, T. S., \& Lewis, G. (2014). Sibling bullying and risk of depression, anxiety and self-harm: A prospective cohort study. Pediatrics, 134(4), 10321039. doi:10.1542/peds.2014-0832

Buist, K. L., Deković, M., \& Prinzie, P. (2013). Sibling relationship quality and psychopathology of children and adolescents: A meta-analysis. Clinical Psychology Review, 33(1), 97-106. doi:10.1016/j.cpr.2012.10.007

Campione- Barr, N. \& Smetana, J. G. (2010). "Who said you could wear my sweater?" Adolescent siblings' conflicts and associations with relationship quality. Child Development, 81(2), 464471. doi:10.1111/j.14678624.2009.01407.x 
Cizek, G. J., Bowen, D., \& Church, K. (2010). Sources of validity evidence for educational and psychological tests: A follow-up study. Educational and Psychological Measurement, 70(5), 732-743.

doi:10.1177/0013164410379323

Deutsch, M., Coleman, P. T., \& Marcus, E. C. (Eds.). (2006). The handbook of conflict resolution: Theory and resolution $\left(2^{\text {nd }}\right.$ ed.). San Fransisco, CA: Jossey-Bass.

Eckes, T. (2009). Many-facet Rasch measurement. Hagen: TestDaf Institue. Diakses 11 Januari 2018, dari https://www.researchgate.net/profile/ Thomas_Eckes/publication/228465956 Many-

facet_Rasch_measurement/links/02e7e 529856ced2427000000.pdf.

Ghozali, I. (2017). Structural equations model concepts and application with Amos 24 program. Semarang: Agency Publisher UNDIP.

Gudmundsson, E. (2009). Guidelines for translating and adapting psychological instruments. Nordic Psychology, 61(2), 29-45. doi:10.1027/1901-2276.61.2.29

Harzing, A., Baldueza, J., Barner-Rasmussen, W., Barzantny, C., Canabal, A., Davila, A., ..., Zander, L. (2009). Rating versus ranking: What is the best way to reduce response and language bias in crossnational research? International Business Review, 18(4), 417-432. doi:10.1016/j.ibusrev.2009.03.001

International Test Commission. (2017). The ITC guidelines for translating and adapting tests (Second edition). International Journal of Testing, 18(2), 101-134. doi:10.1080/15305058.2017.1398166

Jeanrie, C., \& Bertrand, R. (1999). Translating tests with the international test commission's guidelines: Keeping validity in mind. European Journal of Psychologyical Assessment, 15(3), 277283. doi:10.1027/1015-5759.15.3.277

Khami, M. R., Razedhi, S., \& Mirmohammadi, S. M. (2016). Developing a questionnaire to assess the knowledge, attitude and practice of health-care workers about blood-borne diseases and its psychometric analysis. Journal of Modern Rehabilitation, 10(1), 35-42.

Kramer, L. (2010). The essential ingredients of successful sibling relationships: An emerging framework for advancing theory and practice. Child Development Perspectives, 4(2), 80-86. doi: 10.1111/j.1750-8606.2010.00122.x

Kramer, L. (2014). Learning emotional understanding and emotion regulation through sibling interaction. Early Education and Development, 25(2), 160-184. doi:10.1080/10409289.2014.838824

Kramer, L., \& Baron, L. A. (1995). Parental perceptions of children's sibling relationships. Family Relations, 44(1), 95-103. doi: 10.2307/584746

McCoach, D. B., Gable, R. K., \& Madura, J. P. (2013). Instrument development in the affective domain ( $3^{\text {rd }}$ ed.). Netherlands: Springer.

Muarifah, A., \& Puspitasari, I. (2018). Hubungan antara pola asuh demokratis dan kecerdasan emosi dengan persaingan antar saudara. Jurnal Psikologi Insight, 2(1), 1-10.

Naibaho, S. T., Victoriana, E., \& Tjoeng, N. T. (2017). Studi deskriptif mengenai sibling relationship pada remaja dengan saudara spektrum autisme. Humanitas, I(2), 103-112.

Perlman, M., Ross, H. S., \& Garfinkel, D. A. (2009). Consistent patterns of 
interaction in young children's conflicts with their siblings. International journal of Behavioral Development, 33(6), 504515. doi:10.1177/0165025409343745

Polit, D. F., Beck, T. C., \& Owen, S. V. (2007). Focus on research methods: Is the CVI an acceptable indicator of content validity? Appraisal and recommendations. Research in Nursing \& Health, 30(4), 459-467. doi:10.1002/nur

Rajput, A. (2014). Siblings' interpretations of conflict: The link between relationship quality and conflict strategies. (Unpublished doctoral thesis). Concordia University, Quebec, Canada.

Recchia, H. E. (2009). Explaining variability in sibling conflict resolution strategies during middle childhood. (Unpublished doctoral thesis). Concordia University, Quebec, Canada.

Recchia, H. E., \& Howe, N. (2009). Associations between social understanding, sibling relationship quality, and siblings' conflict strategies and outcomes. Child Development, 80(5), 1564-1578. doi:10.1111/j.14678624.2009.01351.x

Rodrigues, I. B., Adachi, J. D., Beattie, K. A., \& MacDermid, J. C. (2017). Development and validation of a a new tool to measure the facilitators, barriers and preferences to exercise in people with osteoporosis. BMC Musculoskeletal Disorders, 18(4), 540549. doi:10.1186/s12891-017-1914-5

Ross, H. S. \& Lazinski, M. J. (2014). Parent mediation empowers sibling conflict resolution. Early Education and Development, 25(2), 259-275. doi:10.1080/10409289.2013.788425

Sala, R. L., Galfre, E., Bertani, L., Mingolla, V., Murelli, S., \& Messina, G. (2017). The quality of nursing in intensive care: a development of a rating scale. Acta Biomed for Health Professions, 88(1), 61-68. doi:10.23750/abm.v88i1

Schleien, S., Ross, H., \& Ross, M. (2010). Young children's apologies to their siblings. Social Development, 19(1), 170-186. doi:10.1111/j.14679507.2008.00526.x

Scrimgeour, M. B., Mariotti, E. C., \& Blandon, A. Y. (2017). Children's physiological regulation and sibling conflict as correlates of children's conscience development. Social Development, 26(2), 329-348. doi:10.1111/sode.12194

Sousa, V. D. \& Rojjanasrirat, W. (2010). Translation, adaptation and validation of instruments or scales for use in crosscultural health care research: A clear and user-friendly guideline. Journal of Evaluation in Clinical Practice, 17(2), 268-274. doi:10.1111/j.13652753.2010.01434.x

Sperber, A. D. (2004). Translation and validation of study instruments for cross-cultural research. Gastroenterology, 126, 124-128. doi:10.1053/j.gastro.2003.10.016

Swanepoel, B. A., \& Krüger, C. (2011). Revisiting validity in cross-cultural psychometric test development: A systems-informed shift towards qualitative research designs. South African Journal of Psychiatry, 17(1), 10-15. doi: 10.4102/sajpsychiatry.v17i1.250

Thien, 1. M. \& Ong, M. Y. (2016). The applicability of course experience questionnaire for a Malaysian university context. Quality Assurance in Eduation, 24(1), 41-55. doi:10.1108/qae-08-20140041

Tucker, C. J. \& Finkelhor, D. (2015). The state of interventions for sibling conflict 
and aggression: A systematic review. Trauma, Violence, \& Abuse, 18(4), 396406. doi:10.1177/1524838015622438

Tucker, C. J., Finkelhor, D., Shattuck, A. M., \& Turner, H. (2013). Prevalence and correlates of sibling victimization types. Child Abuse and Neglect, 37(4), 213223. doi:10.1016/j.chiabu.2013.01.006

Turniati, E., \& Nusantoro, E. (2015). Upaya mengatasi sibling rivalry melalui layanan konseling kelompok. Indonesian Journal of Guidance and Counseling: Theory and Application, 4(4), 8-14. doi:10.1136/emermed-2012201170

Viñas Poch, F., González Carrasco, M., Gras Pérez, E., Jane Ballabriga, C., \& Casas Aznar, F. (2015). Psychometric properties of the EATQ-R among a sample of Catalan-speaking Spanish adolescents. Universitas Psychologica, 14(2), 747-758. doi:10.11144/Javeriana.upsy14-2.ppea
Volling, B. L., \& Blandon, A. Y. (2005). Positive indicators of sibling relationship quality: The sibling inventory of behavior. In K. A. Moore \& L. H. Lippman (Ed.). What do children need to flourish? Conceptualizing and measuring indicators of positive development (pp. 203-219). New York: Springer.

Whiteman, S. D., McHale, S. M., \& Soli, A. (2011). Theoretical perspectives on sibling relationships. Journal of Family Theory \& Review, 3(2), 124-139. doi:10.1111/j.1756-2589.2011.00087.x

Zamanzadeh, V., Ghahramanian, A., Rassouli, M., Abbaszadeh, A., AlaviMajd, H., \& Nikanfar, A.-R. (2015). Design and implementation content validity study: Development of an instrument for measuring patientcentered communication. Journal of Caring Sciences, 4(2), 165-178. doi:10.15171/jcs.2015.017 